\title{
Conservation of the Biocatalytic Activity of Whole Yeast Cells by Supported Sol - Gel Entrapment for Efficient Acyloin Condensation
}

\author{
László Nagy-Győr'1, Emese Farkas¹, Mihai Lăcătuș², Gergő Tóth¹, Dániel Incze1, Gábor Hornyánszky¹, \\ Viktória Bódai ${ }^{3,4}$, Csaba Paizs², László Poppe ${ }^{1,2,5}$, Diána Balogh-Weiser ${ }^{1,6^{*}}$ \\ 1 Department of Organic Chemistry and Technology, Faculty of Chemical Technology and Biotechnology, \\ Budapest University of Technology and Economics, H-1521 Budapest, P. O. B. 91, Hungary \\ ${ }^{2}$ Biocatalysis and Biotransformation Research Center, Babeş-Bolyai University of Cluj-Napoca, \\ Arany János str. 11, Ro-400028 Cluj-Napoca, Romania \\ ${ }^{3}$ Fermentia Ltd, $\mathrm{H}-1045$ Budapest, Berlini str. 45-47., Hungary \\ ${ }^{4}$ Witaria Ltd, H-1087 Budapest, Luther str. 4-6, Hungary \\ ${ }^{5}$ SynBiocat LLC, H-1172 Budapest, Szilasliget str. 3., Hungary \\ ${ }^{6}$ Department of Physical Chemistry and Materials Science, Faculty of Chemical Technology and Biotechnology, \\ Budapest University of Technology and Economics, H-1521 Budapest, P. O. B. 91, Hungary \\ * Corresponding author, e-mail: dweiser@mail.bme.hu
}

Received: 05 July 2019, Accepted: 27 September 2019, Published online: 12 December 2019

\begin{abstract}
In this study, an efficient and generally applicable $2^{\text {nd }}$ generation sol - gel entrapment method was developed for immobilization of yeast cells. Cells of Lodderomyces elongisporus, Candida norvegica, Debaryomyces fabryi, Pichia carsonii strains in admixture with hollow silica microspheres support were immobilized in sol - gel matrix obtained from polycondensation of tetraethoxysilane. As biocatalysts in the selective acyloin condensation of benzaldehyde catalyzed by pyruvate decarboxylase of the yeast, the novel immobilized whole-cell preparations were compared to other states of the cells such as freshly harvested wet cell paste, lyophilized cells and sol - gel entrapped preparations without hollow silica microspheres support. Reusability and storability studies designated this novel $2^{\text {nd }}$ generation sol gel method as a promising alternative for solid formulation of whole-cells bypassing expensive and difficult downstream steps while providing easy-to-handle and stable biocatalysts with long-term preservation of the biocatalytic activity.
\end{abstract}

Keywords

yeast, whole-cell, immobilization, biocatalysis, acyloin condensation

\section{Introduction}

The biocatalytic systems based on whole-cells are blooming recently, due to the continuously growing interest on synthetic biology, protein engineering and recombinant techniques providing novel cells with extremely widespread biocatalytic activity of various origin $[1,2]$. In addition, the more and more screening tools for novel enzymatic activities within cells opens up new possibilities to realize various valuable biocatalytic processes with wild type cells as well. Whole-cell biocatalysts have many advantages compared to the isolated enzymatic systems, especially the avoidance of expensive and time-consuming downstream processes including enzyme purification represents significant benefits. Moreover, whole-cells containing natural co-factors, co-enzymes and their natural regeneration systems offer ideal environment for works with cofactor requiring enzymes [3, 4]. On the other hand, the whole-cells suffer a few drawbacks such as low tolerance of organic solvents, difficult co-factor regeneration and sometimes lower activities and side reactions [5].

Among whole-cells, yeasts represent one of the most traditional biocatalyst. While yeast cells can express diverse enzymatic activities, they are easy-to produce and handle, stable and commonly non-pathogenic. Their redox, C-C coupling or hydrolytic enzyme sets get significant attention in several syntheses of chiral intermediates or compounds [6-10]. Amongst the yeast catalyzed biotransformations, the carbon-carbon condensation is one of the most important reaction to produce optically 
pure pharmaceutically active ingredients (APIs) like $(R)$-phenylacetyl carbinol being the precursor of ephedrine and pseudoephedrine [11, 12]. Pyruvate decarboxylase (PDC, EC 4.1.1.1) - as a valuable member of the natural enzyme toolbox of yeasts - can catalyze the non-oxidative decarboxylation of pyruvate to acetaldehyde. Within the same enzyme, the accumulated acetaldehyde can react with activated acetaldehyde forming acetoin (3-oxo-2-butanol). Some yeasts, such as various Saccharomyces, Zymomonas, Candida or Hansenula strains, are able to catalyze the carbon-carbon condensation of several aromatic aldehyde analogues with the activated acetaldehyde leading to valuable acyloins $[13,14]$.

Immobilization of cells and enzymes has been researched simultaneously since many decades. Even today - due to the extremely expanding requirements of biotechnology enzyme and cell immobilization is a rapidly developing area. The main aims of immobilization strategies are the isolation, compartmentalization and stabilization of the valuable cells, cell organelles or enzymes with high biocatalytic activity [14-18]. Although several immobilization methods and carrier systems for cells or enzymes are based on similar methods (binding reactions and media, carrier materials etc.), in many instances enzyme and cell immobilization require significantly different approaches.

Among cell immobilization techniques, adsorption on tissue-like or macroporous solid supports and entrapment in gel matrices such as alginate, polyacrylamide, carrageenan, chitosan or agar based matrices are used commonly [18-23]. In most of these cases, traditional organic materials are applied which are natural, biocompatible, commercially available and easy-to-handle. In many instances, however, the stability, durability, mechanical and chemical resistance of the resulted immobilized whole-cell preparations based on such traditional natural materials are not satisfactory for certain applications [24, 25].

The sol - gel systems based on polycondensation of various alkoxysilane precursors can provide porous organo-silica network with fine-tunable properties for many smart application such as embedding several biological components from small biomolecules to cells with enhanced stability [23, 26-28], sensor or optical development [29-31]. Tetraethoxysilane (TEOS) was successfully used as precursor material for sol - gel immobilization of plant and bacterial cells $[26,30,32-34]$. The resistance of yeast (Saccharomyces cerevisiae) cells entrapped in sol - gel matrices in different organic media was studied earlier indicating that the sol - gel network could protect the living cells against the lethal effect of organic solvents. A mixture of tetra-, tri- and diethoxysilane precursors was also applied for immobilization of baker yeast demonstrating increased stability and biocatalytic activity of the immobilized cells in sucrose degradation $[35,36]$. In our previous report, co-immobilization of two different types of whole-cells - recombinant Escherichia coli cells expressing $\omega$-transaminase and Lodderomyces elongisporus cells with ketoreductase activity - was developed by their simultaneous entrapment in a sol - gel system [4].

In this study, the biocatalytic potential of yeast cells of four different strains (Candida norvegica, Debaryomyces fabryi, Lodderomyces elongisporus and Pichia carsonii) were examined in acyloin condensation of benzaldehyde (1). Biocatalytic ability of different forms of the yeast cells in the acyloin condensation catalyzed by the PDCs present in the different yeasts were compared involving freshly harvested cell pellets, lyophilized cells and two different immobilized forms of freshly harvested cells [1. entrapped in simple $1^{\text {st }}$ generation sol - gel matrices (nanoporous network from TEOS as precursor) and 2. entrapped in a $2^{\text {nd }}$ generation supported sol - gel system (nanoporous network from TEOS as precursor supported by hollow silica microspheres)] which has not been reported earlier (Fig. 1). The effect of co-factors such as thiamine pyrophosphate (TPP) and magnesium chloride and different buffer systems were also studied. The reusability and storability of immobilized wholecell biocatalysts were examined as well.

\section{Materials and methods}

\subsection{Materials}

\subsubsection{Reagents, chemicals and cells}

Except otherwise not stated, all chemicals and starting materials were purchased from Sigma-Aldrich (St. Louis, MO, USA), Fluka (Milwaukee, WI, USA) or Alfa Aesar Europe (Karlsruhe, Germany). MAT540 (MATSPHERETM SERIES 540 - hollow silica microspheres covered with aminoalkyl and vinyl functions) was purchased from Materium Innovations (Granby, Canada). Yeast srains were stored in lyophilized ampules in Witaria's strain culture collection (Candida norvegica: WY4, Debaryomyces fabryi: WY11, Lodderomyces elongisporus: WY2 and Pichia carsonii: WY1). Yeasts were maintained and cultivated on Yeast Malt Agar (HiMedia M424) and Yeast Malt Broth (HiMedia M425). Cultivation was carried out as described earlier [10] in a $10 \mathrm{~L}$ fermenter. 


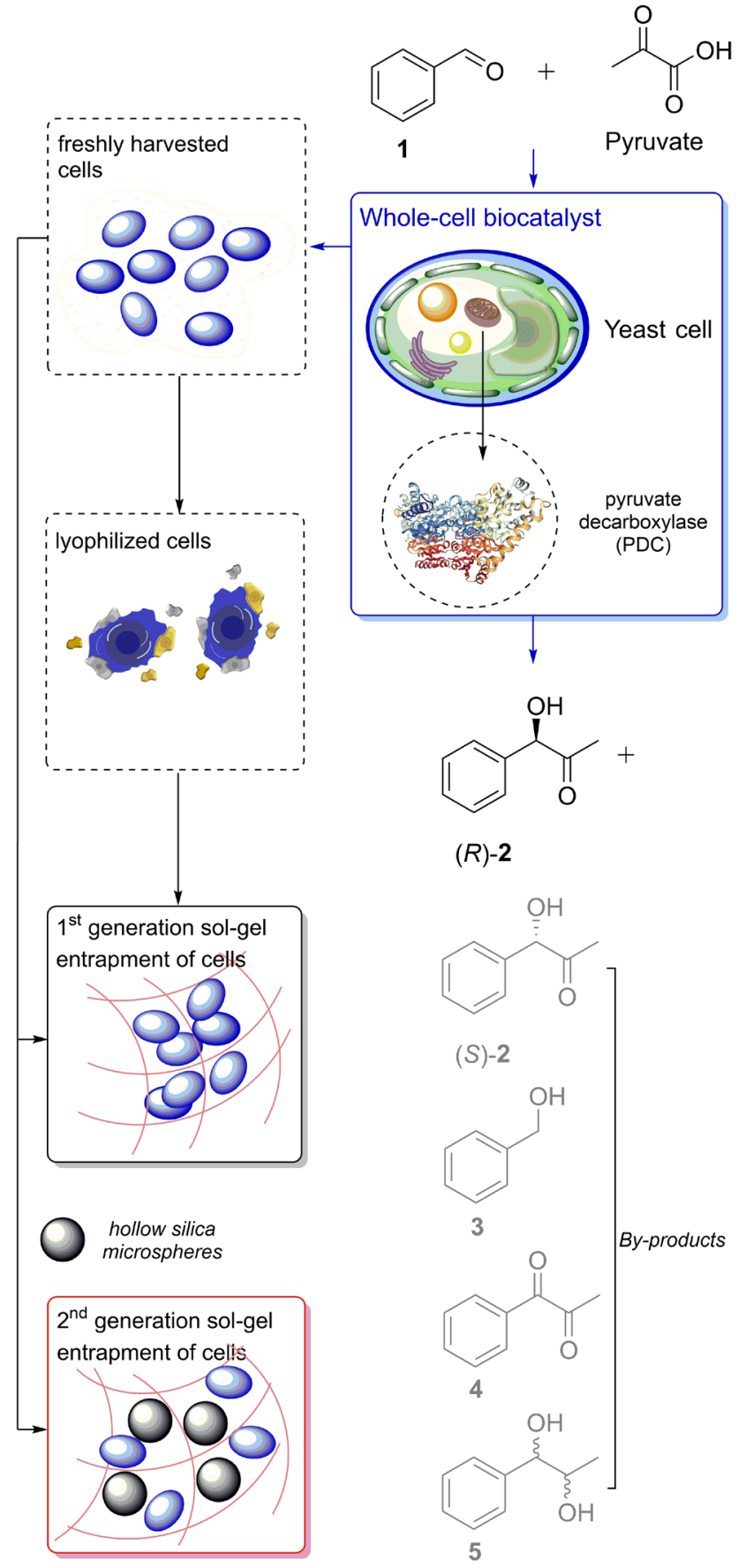

Fig. 1 Acyloin condensation of benzaldehyde (1) catalyzed by yeast cells in four different forms: 1 . freshly harvested cells, 2. lyophilized cells, 3. cells entrapped in simple $1^{\text {st }}$ generation sol - gel matrix and

4. cells entrapped in $2^{\text {nd }}$ generation, hollow silica microspheres supported sol - gel matrix.

\subsubsection{Equipment}

Substrate (1) and products $[(R)-\mathbf{2},(S)-\mathbf{2}, \mathbf{3}, 4$ and 5] obtained in the biotransformations were analyzed by GC with an Agilent 4890 equipment with FID detector and
Hydrodex $\beta$-6TBDM column $[25 \mathrm{~m} \times 0.25 \mathrm{~mm} \times 0.25 \mu \mathrm{m}$ film with heptakis-(2,3-di-O-methyl-6-O-t-butyldimethylsilyl)- $\beta$-cyclodextrine; Macherey \& Nagel] using $\mathrm{H}_{2}$ carrier gas (injector: $250{ }^{\circ} \mathrm{C}$, detector: $250{ }^{\circ} \mathrm{C}$, head pressure: 12 psi, split ratio: 50:1). The temperature program for $\mathrm{GC}$ analysis was $15 \mathrm{~min}$ at $120{ }^{\circ} \mathrm{C}, 120-150{ }^{\circ} \mathrm{C}, 5{ }^{\circ} \mathrm{C} \mathrm{min}-1$, $10 \mathrm{~min}$ at $150{ }^{\circ} \mathrm{C}$ in each cases (Table 1 ).

The morphology of the freshly harvested cells was described by Olympus BX-43 light microscope and the immobilized biocatalysts was investigated with a JEOL JSM-5500LV scanning electron microscope (SEM). For SEM analysis samples were covered with gold, then electron beam energy of $10 \mathrm{kV}$ was used.

\subsection{Methods}

\subsubsection{Production of freshly harvested yeast cells}

After cultivation, cells were centrifuged and washed with phosphate buffer (100 mM, pH 7.0), then the buffer was decanted and the residue was stored at $4{ }^{\circ} \mathrm{C}$ until use.

\subsubsection{Lyophilization of cells}

Following cultivation, the cell lyophilization was carried out as described earlier [10].

\subsubsection{Immobilization of cells by the $1^{\text {st }}$ generation sol - gel method}

Silica sol was prepared by addition of tetraethoxysilane (TEOS, $0.72 \mathrm{~mL})$ to a solution of distilled water $(0.25 \mathrm{~mL})$ containing $0.1 \mathrm{M} \mathrm{HNO}_{3}(65 \mu \mathrm{L})$ followed by sonication of the resulted mixture for $5 \mathrm{~min}$ at RT (Emag Emmi 20HC Ultrasonic Bath, $45 \mathrm{kHz}$ ) and cooling at $4{ }^{\circ} \mathrm{C}$ for $24 \mathrm{~h}$. In case of simple sol-gel entrapment, cell paste $(0.5 \mathrm{~g})$ was suspended in phosphate buffer $(3 \mathrm{~mL}, 0.1 \mathrm{M}, \mathrm{pH} 7.5)$ than silica sol was mixed with the cell suspension and the resulted mixture was shaken (Technokartell Test Tube Shaker Model T3SK, $40 \mathrm{~Hz}$ ) at RT for $5 \mathrm{~min}$. After gelation at RT (occurred within $30 \mathrm{~min}$ ), the resulted gel was aged at $4{ }^{\circ} \mathrm{C}$ for $48 \mathrm{~h}$. The crude biocatalyst was washed with phosphate buffer $(2 \times 15 \mathrm{~mL}$, $100 \mathrm{mM}, \mathrm{pH} 7.5)$, centrifuged and dried at room temperature (24 h), and stored at $4{ }^{\circ} \mathrm{C}$.

Table 1 Retention times and response factors used for determination of conversion and enantiomer composition

\begin{tabular}{ccccccc}
\hline \multicolumn{4}{c}{ Retention times (min) } & & Response factors \\
\hline $\mathbf{1}$ & $(R)-\mathbf{2}$ & $(S)-\mathbf{2}$ & $\mathbf{3}$ & $\mathbf{4}$ & $\mathbf{5}$ & $\mathbf{1}: \mathbf{2 : \mathbf { 3 }}$ \\
3.0 & 8.9 & 9.6 & 5.1 & 4.2 & 19.3 & $1.1: 0.85: 1$ \\
\hline
\end{tabular}


2.2.4 Immobilization of cells by the $2^{\text {nd }}$ generation sol-gel method using hollow silica microspheres as support

In case of $2^{\text {nd }}$ generation sol - gel entrapment, a suspension was prepared by addition of MAT540 support (150 mg) to freshly harvested $(0.5 \mathrm{~g})$ yeast cells resuspended in phosphate buffer ( $3 \mathrm{~mL}, 0.1 \mathrm{M}, \mathrm{pH} 7.5)$. The supported cells were shaken (Technokartell Test Tube Shaker Model T3SK, $40 \mathrm{~Hz}$ ) until became homogeneous suspension (cc. $5 \mathrm{~min}$ at RT). The following steps were the same as previously described in the case of simple sol - gel entrapment. Cell immobilization yield ( $Y_{\text {IC }}, \%$ ) was over $99 \%$ as determined by viable cells counting on dilution plates and Helber counting chambers as previously described [4].

\subsubsection{Acyloin condensation of benzaldehyde 1 catalyzed by freshly harvested or lyophilized yeast cells}

A suspension of yeast cells (150 mg of cell paste or lyophilized cells) in phosphate buffer (5 mL, $100 \mathrm{mM}, \mathrm{pH} 7.0)$ was incubated with sodium pyruvate ( 2 equiv., $41.4 \mathrm{mg}$ ) in a $10 \mathrm{~mL}$ test tube at $25^{\circ} \mathrm{C}$ for $1 \mathrm{~h}$, followed by addition of a solution of benzaldehyde $(1,40 \mathrm{mM})$ in 2-propanol $(100 \mu \mathrm{L})$. The reaction was conducted with orbital shaking at $25^{\circ} \mathrm{C}$ and $750 \mathrm{rpm}$. Samples were taken after $3 \mathrm{~h}$ of reaction time, extracted with ethyl acetate $(600 \mu \mathrm{L})$ dried over $\mathrm{Na}_{2} \mathrm{SO}_{4}$ and analyzed by GC as described in Subsection 2.1.2.

\subsubsection{Acyloin condensation of benzaldehyde 1 catalyzed by sol - gel immobilized yeast cells}

A suspension of immobilized yeast cell biocatalyst $(150 \mathrm{mg})$ in different buffer (2.5 mL, $50 \mathrm{mM}$, $\mathrm{pH}$ 5.0-7.0) was supplemented with sodium pyruvate ( 3 equiv., $32 \mathrm{mg}$ ) in a $5 \mathrm{~mL}$ test tube at $25^{\circ} \mathrm{C}$, followed by addition of a solution of benzaldehyde $(1,40 \mathrm{mM})$ in 2-propanol $(100 \mu \mathrm{L})$. The reaction was conducted with orbital shaking at $25^{\circ} \mathrm{C}$ and $750 \mathrm{rpm}$. Samples were taken after $3 \mathrm{~h}$ of reaction time, extracted with ethyl acetate $(600 \mu \mathrm{L})$ dried over $\mathrm{Na}_{2} \mathrm{SO}_{4}$ and analyzed by GC. The conversion, product distribution and enantiomeric excess of the acyloin product $(R)-\mathbf{2}$ were determined by GC as described in Subsection 2.1.2.

\subsubsection{Effect of co-factors and buffer systems on acyloin condensation of benzaldehyde 1 catalyzed by sol - gel entrapped yeast cells}

The acyloin condensation of benzaldehyde $\mathbf{1}$ catalyzed by Lodderomyces elongisporus yeast cells entrapped in $2^{\text {nd }}$ generation sol-gel systems were carried out under similar conditions as described in Subsection 2.2.6 and in the presence of thiamine pyrophosphate (TPP: $10 \mathrm{n} / \mathrm{n} \%$ and $\mathrm{MgCl}_{2}: \mathrm{n} / \mathrm{n} \%$ ). The effect of co-factors was examined in the following buffer systems: citrate $(0.05 \mathrm{M}, \mathrm{pH} 5.0)$, acetate (0.05 M, pH 5.0), citrate (0.05 M, pH 5.5), acetate $(0.05 \mathrm{M}, \mathrm{pH} 5.5)$, citrate $(0.05 \mathrm{M}, \mathrm{pH} 6.0)$, phosphate (0.05 M, pH 6.5) and phosphate (0.05 M, pH 7.0).

\subsubsection{Reusability of the sol - gel entrapped yeast cell biocatalyst}

The reusability of Lodderomyces elongisporus yeast cells entrapped in $2^{\text {nd }}$ generation sol - gel systems (Le-SG-2) was investigated in acyloin condensation reactions as described in Subsection 2.2.6 repeated five times. After a reaction, the immobilized biocatalyst was isolated by filtration (glass filter G4) and washed with phosphate buffer $(5 \mathrm{~mL}$, $100 \mathrm{mM}, \mathrm{pH}$ 7.0) three times and dried to constant weight. The mass of the biocatalyst was measured to ensure the constant reaction conditions in every reaction cycle.

\subsubsection{Storage stability of the sol - gel entrapped yeast cell biocatalyst}

The long-term stability or storability of the Lodderomyces elongisporus yeast cells entrapped in $2^{\text {nd }}$ generation sol - gel systems (Le-SG-2) was investigated by biocatalytic activity determination in acyloin condensation of benzaldehyde (1) as described in Subsection 2.2.5. During the examined time period (6 month), biocatalyst was stored at $4{ }^{\circ} \mathrm{C}$.

\subsubsection{Calculations}

Conversion of the substrate $(c, \%)$, enantiomeric excess $(e e, \%)$, molar percentage of the components $(x, \%)$ and molar ratio of acyloin $(R)-\mathbf{2}$ and alcohol 3, specific biocatalyst activity $\left(U_{\mathrm{B}}, \mathrm{U} \mathrm{g}^{-1}\right)$ and cell content based specific activity $\left(U_{\mathrm{C}}, \mathrm{U} \mathrm{g}^{-1}\right)$ were calculated at $3 \mathrm{~h}$ by using Eqs. (1)-(5) based on data measured by GC:

$c[\%]=100-\frac{n_{\mathrm{S}}}{n_{\mathrm{S}}+n_{\mathrm{P}}} \times 100$

where $n_{\mathrm{S}}$ and $n_{\mathrm{P}}$ are the molar amounts of substrate $(S)$ and product(s) $(P)$,

$e e[\%]=\frac{n-n^{*}}{n+n^{*}} \cdot 100$

where $n$ and $n^{*}$ are the molar amounts of the major and the minor enantiomer,

$$
\begin{gathered}
x[\%]=\frac{n_{\mathrm{P}}}{n_{\mathrm{S}}+\sum n_{\mathrm{P}}} \times 100 \\
U_{\mathrm{B}}\left[\mathrm{U} \mathrm{g}^{-1}\right]=\frac{\left(n_{\mathrm{S}} \times c\right)}{\left(t \times m_{\mathrm{B}}\right)}
\end{gathered}
$$


where $\mathrm{U}$ is rate of the substrate conversion $\left[\mu \mathrm{mol} \mathrm{min}{ }^{-1}\right.$, $t$ is reaction time, $m_{\mathrm{B}}$ is the mass of the biocatalyst,

$U_{\mathrm{C}}\left[\mathrm{Ug} \mathrm{g}^{-1}\right]=\frac{\left(n_{\mathrm{S}} \times c\right)}{\left(t \times m_{\mathrm{C}}\right)}$

where $m_{\mathrm{C}}$ is the mass of the cells in the immobilized biocatalyst.

\section{Results and discussion}

Based on scientific reports and our previous knowledge on microbial screening of ketoreductase activities in various yeast strains [7, 10,37-40], four different yeast strains (Candida norvegica, Debaryomyces fabryi, Lodderomyces elongisporus and Pichia carsonii) were selected for investigating their biocatalytic activity in the acyloin condensation of benzaldehyde (1). First, two different forms of non-immobilized yeast cells - freshly harvested cell paste and lyophilized cells powder - were screened as biocatalysts with acyloin forming ability (Table 2). While only ketoreductase activity was detectable with the freshly harvested cell paste without observable PDC activity, the lyophilized cell form of all the four investigated strains resulted in formation of the acyloin product $(R)-2$ with moderate to good conversion $\left(c_{1}=17-100 \%\right)$, acceptable to excellent acyloin ratio $(R=0.47-21$, the molar ratio of acyloin (R)-2 and alcohol 3) and in high enantiomeric excess $\left(e e_{(R)-2} \geq 89 \%\right)$. These difference in acyloin forming ability can be attributed to inactivation of the most active ketoreductases on lyophilization due to the significantly different water content of the cell paste and lyophilized cells. The lyophilized cells of Lodderomyces elongisporus proved to be the most efficient acyloin producing biocatalyst providing the highest quantity the acyloin product $(R)-2(x=59 \%)$ with high enantiopurity (ee = 96\%).

Thus, yeast cells from Lodderomyces elongisporus were selected for further cell immobilization experiments involving two different sol - gel systems. The simple, $1^{\text {st }}$ generation sol - gel method was based only tetraethoxysilane (TEOS) as monomers to form a nanoporous network entrapping the cells. In case of the $2^{\text {nd }}$ generation sol - gel method, wholecells and a proper inert solid support were co-immobilized. Hollow silica microspheres with amino/vinyl grafted surface (M540) were previously described as efficient enzyme carrier [41, 42], thus M540 was tried in $2^{\text {nd }}$ generation sol - gel systems as support material as well.

The two sol - gel entrapment methods with freshly harvested cell paste were investigated by testing the acyloin forming ability of the immobilized cell biocatalysts from benzaldehyde (1). Although the different forms of whole-cells exhibited comparable biocatalytic activity $\left(U_{\mathrm{B}}\right)$ in consuming benzaldehyde $(\mathbf{1})$, the specific biocatalytic activity $\left(U_{\mathrm{C}}\right)$ related to the cell content of the biocatalysts differed significantly (Table 3), being almost twice as high of the $2^{\text {nd }}$ generation sol - gel preparation compared to the freshly harvested cell paste. In addition, fresh cell paste and $1^{\text {st }}$ generation, support-free sol - gel systems exhibited almost exclusively alcohol dehydrogenase activity, while the PDC activity leading to acyloin product with remarkable enantiopurity could be observed only with the lyophilized whole-cells and with the $2^{\text {nd }}$ generation supported / sol - gel entrapped biocatalyst.

The successful co-embedding of the Lodderomyces elongisporus yeast cells (typical cell size 3-10 $\mu \mathrm{m}$, Fig. 2 A) and the hollow silica microspheres (mean particle size 10-20 $\mu \mathrm{m}$, Fig. 2 B) within the sol - gel network can be seen on the scanning electron microscopy (SEM) image of the $2^{\text {nd }}$ generation sol - gel biocatalyst (Fig. 2 C), where compact particles can be observed with 50-70 $\mu \mathrm{m}$ diameter.

Thiamine pyrophosphate (TPP) and $\mathrm{MgCl}_{2}$ are known co-factors for PDC [43, 44], thus the effect of addition of TPP and $\mathrm{MgCl}_{2}$ to different buffer systems was studied in the acyloin condensation of 1 catalyzed by the $2^{\text {nd }}$ generation sol-gel form of Lodderomyces elongisporus (Le-SG-2) (Fig. 3). Supplementation of the reaction with TPP and $\mathrm{MgCl}_{2}$ had enhancing effect on the biocatalytic activity at each $\mathrm{pH}$ between 5.0-7.0 (Fig. 3 A). The pH influenced

Table 2 Screening of yeast cells from different strains in their freshly harvested and lyophilized forms for acyloin condensation of substrate $\mathbf{1}$.

\begin{tabular}{|c|c|c|c|c|c|c|c|c|}
\hline \multirow[b]{2}{*}{ Strain } & \multicolumn{2}{|c|}{$c_{1}(\%)$} & \multicolumn{2}{|c|}{$e e_{(R)-2}(\%)$} & \multicolumn{2}{|c|}{$R^{\mathrm{a}}$} & \multicolumn{2}{|c|}{$x_{2}(\%)^{b}$} \\
\hline & $\begin{array}{c}\text { freshly } \\
\text { harvested }\end{array}$ & lyophilized & $\begin{array}{c}\text { freshly } \\
\text { harvested }^{\mathrm{c}}\end{array}$ & lyophilized & $\begin{array}{c}\text { freshly } \\
\text { harvested }^{\mathrm{c}}\end{array}$ & lyophilized & $\begin{array}{c}\text { freshly } \\
\text { harvested }^{c}\end{array}$ & lyophilized \\
\hline Candida norvegica & $23 \pm 0.9$ & $17 \pm 1.6$ & n.a. & $89 \pm 1.8$ & n.a. & 21.0 & 0 & $17 \pm 0.5$ \\
\hline Debaryomyces fabryi & 100 & 100 & n.a. & $95 \pm 0.3$ & n.a. & 0.45 & 0 & $31 \pm 1.3$ \\
\hline Lodderomyces elongisporus & 100 & 100 & n.a. & $96 \pm 0.4$ & n.a. & 1.4 & 0 & $59 \pm 1.2$ \\
\hline Pichia carsonii & $90 \pm 2.5$ & $98 \pm 0.1$ & n.a. & $96 \pm 1.4$ & n.a. & 1.2 & 0 & $53 \pm 0.9$ \\
\hline
\end{tabular}

${ }^{\mathrm{a}} R$ corresponds to molar ratio of acyloin $(R)-\mathbf{2}$ and alcohol 3.; ${ }^{\mathrm{b}} x_{2}$ is the amount of $(R)-\mathbf{2}$ in the mixture, calculated from GC data; ${ }^{\mathrm{c}}$ No acyloin product $(R)-2$ could be detected. 
Table 3 Comparison of different form of whole-cells from Lodderomyces elongisporus as biocatalysts in biotransformations from $\mathbf{1}$.

\begin{tabular}{lcccc}
\hline $\begin{array}{l}\text { Whole-cell } \\
\text { biocatalyst }\end{array}$ & $\begin{array}{c}U_{\mathrm{B}}^{\mathrm{a}} \\
\left(\mathrm{U} \mathrm{g} \mathrm{g}^{-1}\right)\end{array}$ & $\begin{array}{c}U_{\mathrm{C}}^{\mathrm{b}} \\
\left(\mathrm{U} \mathrm{g}^{-1}\right)\end{array}$ & $\begin{array}{c}e e_{(R)-2} \\
(\%)\end{array}$ & $\begin{array}{c}x_{2}{ }^{\mathrm{c}} \\
(\%)\end{array}$ \\
\hline freshly harvested & $20.9 \pm 0.5^{\mathrm{d}}$ & $20.9 \pm 0.5^{\text {d }}$ & n.a. ${ }^{\mathrm{d}}$ & n.a. ${ }^{\mathrm{d}}$ \\
lyophilized & $20.5 \pm 0.3$ & $22.8 \pm 0.3$ & $98 \pm 0.4$ & $36 \pm 1.5$ \\
$1^{\text {st }}$ gen. sol - gel & $20.9 \pm 0.2^{\mathrm{d}}$ & $33.4 \pm 0.3^{\mathrm{d}}$ & n.a. ${ }^{\mathrm{d}}$ & n.a. ${ }^{\mathrm{d}}$ \\
$2^{\text {nd }}$ gen. sol - gel & $19.2 \pm 0.4$ & $36.5 \pm 0.8$ & $99 \pm 0.4$ & $44 \pm 1.8$ \\
\hline
\end{tabular}

${ }^{\text {a }} U_{\mathrm{B}}$ biocatalytic activity, ${ }^{\mathrm{b}} U_{\mathrm{C}}$ specific biocatalytic activity,

${ }^{c} x_{2}$ is the amount of $(R)-\mathbf{2}$ in the mixture, calculated from $\mathrm{GC}$ data.

${ }^{\mathrm{d}}$ No acyloin product $(R)-\mathbf{2}$ could be detected.

the selectivity towards the PDC-catalyzed acyloin condensation (Fig. 3 B). Among the different buffer systems, phosphate buffer at $\mathrm{pH} 7.0$ led to the highest quantity of the acyloin product $(R)-2(x=70 \%)$.

Reusability of biocatalyst is a key issue, especially when a sustainable process based on biotransformation should be developed. The durability of the $2^{\text {nd }}$ generation sol - gel system-based Lodderomyces elongisporus biocatalyst (Le-SG-2) was investigated in five consecutive reactions for acyloin condensation of $\mathbf{1}$ (Fig. 4). Although with some fluctuation, the total biocatalytic activity $\left(U_{\mathrm{B}}\right)$ and the PDC activity (based on $x_{2}$ ) of the Le-SG-2 biocatalyst were preserved after the five repeated cycles. This is a promising result, considering the severe sensitivity and recovery problems with the freshly harvested cell paste or the lyophilized cell powder.

The most promising Le-SG-2 biocatalyst was also investigated before and after use with scanning electron microscopy (SEM). SEM investigation revealed, that the characteristic morphology of the freshly prepared immobilized biocatalyst - solid irregular particles with 30-60 $\mu \mathrm{m}$ mean particle size - could be preserved in the reusability experiments (Fig. 5).

Long-term storability of biocatalysts under easily sustainable conditions - such as storage at room temperature or in a common refrigerator $\left(4<T<8{ }^{\circ} \mathrm{C}\right)$ - is commonly a required issue. Thus, a test of the residual biocatalytic activity of the Lodderomyces elongisporus cells in acyloin formation from benzaldehyde 1 (residual $U_{\mathrm{B}}, \%$, relative to the initial biocatalytic activity); used as wet cell paste, lyophilized cell powder and as the two sol - gel encapsulated ( $1^{\text {st }}$ and $2^{\text {nd }}$ generation) was performed after 6-month storage at $4{ }^{\circ} \mathrm{C}$ (Table 4$)$.

While the non-immobilized wet cell paste lost all biocatalytic activity, the lyophilized cell powder and the $1^{\text {st }}$
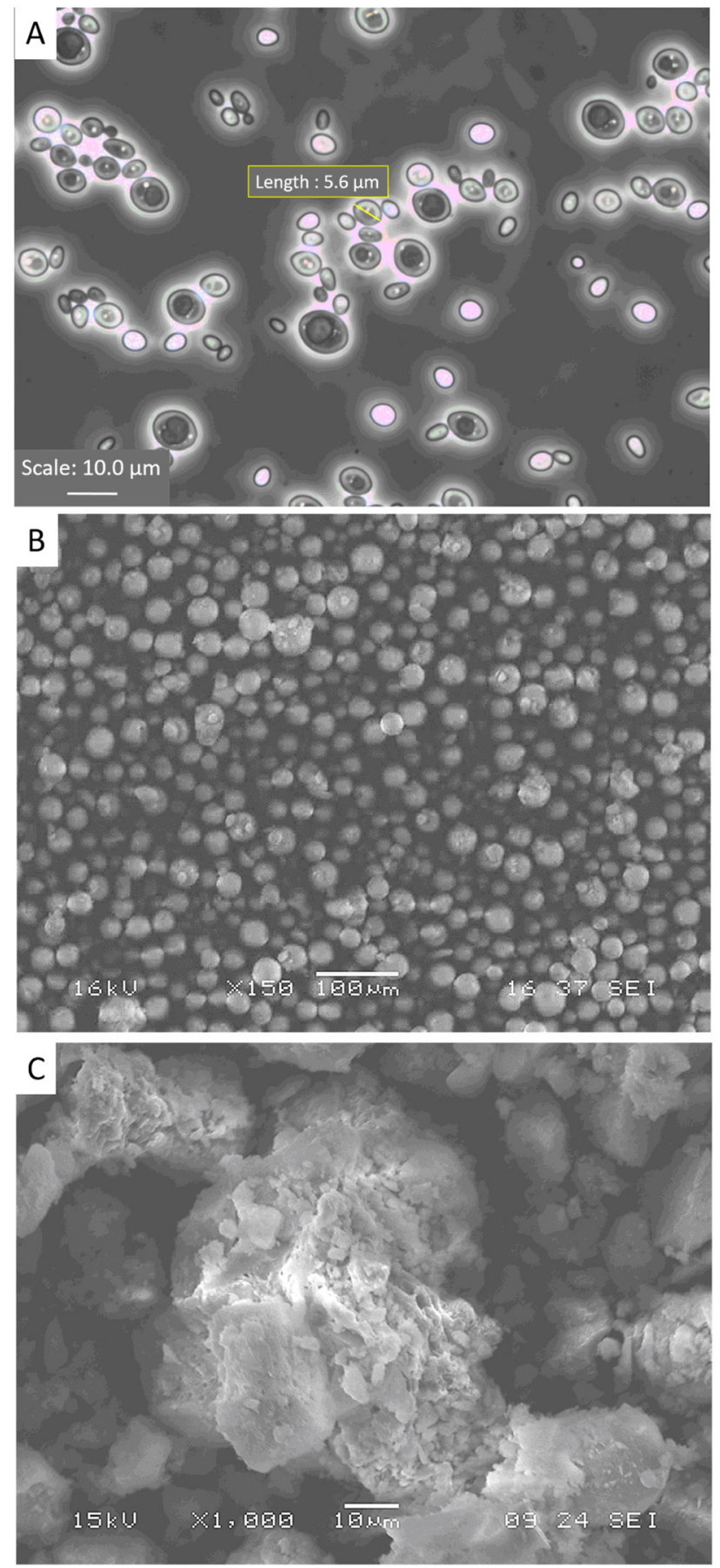

Fig. 2 Microscopic images of freshly harvested Lodderomyces elongisporus cells A, hollow silica microspheres B and freshly harvested Lodderomyces elongisporus cells immobilized in $2^{\text {nd }}$ generation (supported with hollow-silica microspheres) sol - gel system C

generation sol - gel system could preserve mostly the alcohol dehydrogenase activity. Fortunately, the $2^{\text {nd }}$ generation sol - gel system-based Lodderomyces elongisporus biocatalyst could conserve the PDC activity quite efficiently. 

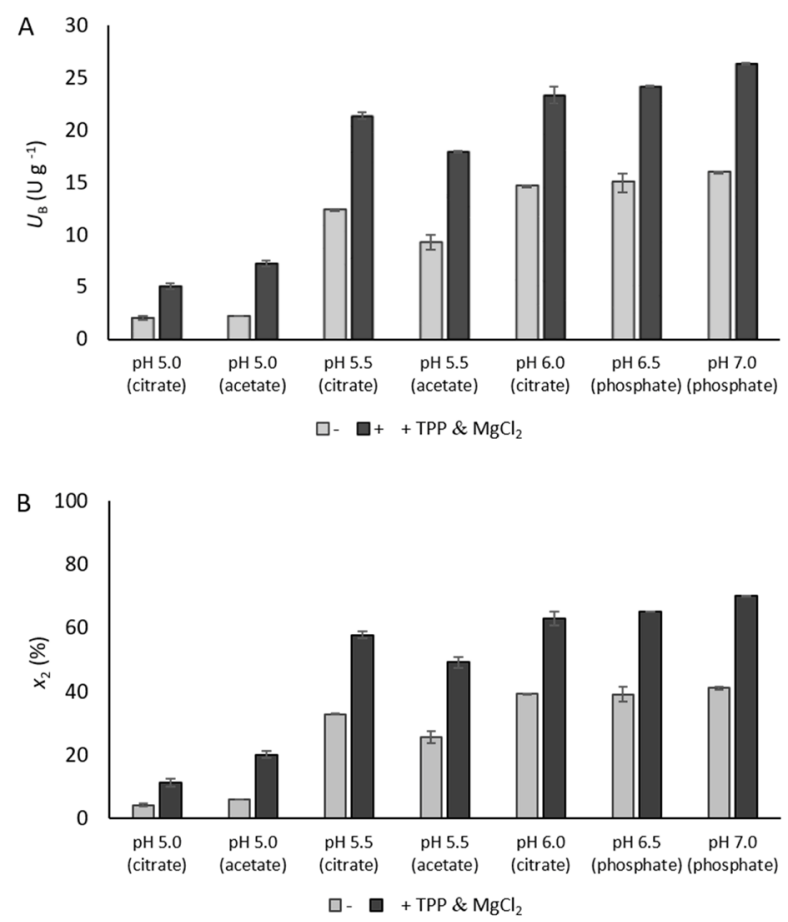

Fig. 3 Effect of supplementation of Lodderomyces elongisporus whole-cells immobilized in $2^{\text {nd }}$ generation sol - gel system with TPP and $\mathrm{MgCl}_{2}$ co-factors on A the biocatalytic activity $\left(U_{\mathrm{B}}\right)$ and on B the acyloin product $(R)-\mathbf{2}$ formation $\left(x_{2}\right)$ from benzaldehyde $\mathbf{1}$ at various $\mathrm{pH}$ in different buffer systems.

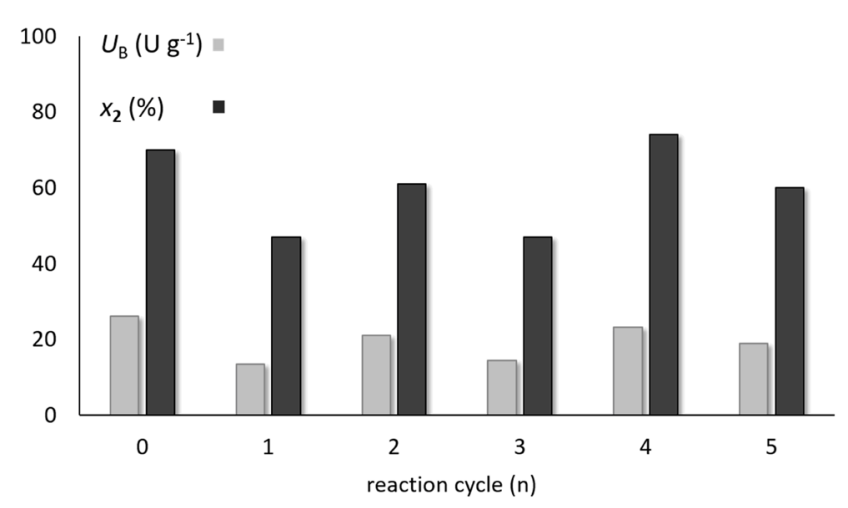

Fig. 4 The changes of biocatalytic activity $\left(U_{\mathrm{B}}\right) \varpi$ of Lodderomyces elongisporus whole-cells in $2^{\text {nd }}$ generation sol - gel systems (Le-SG-2) and the $(R)-2$ formation 1 in acyloin condensation of 1 during 5 cycle reusability.

\section{Conclusion}

A novel, so-called $2^{\text {nd }}$ generation cell immobilization method was developed based on sol - gel technique enabling in situ co-immobilization of yeast whole-cells and hollow silica microspheres as solid support material. This immobilization method could convert Lodderomyces elongisporus yeast cells to stable immobilized biocatalyst with pyruvate decarboxylase activity capable of performing acyloin condensation of benzaldehyde $\mathbf{1}$.
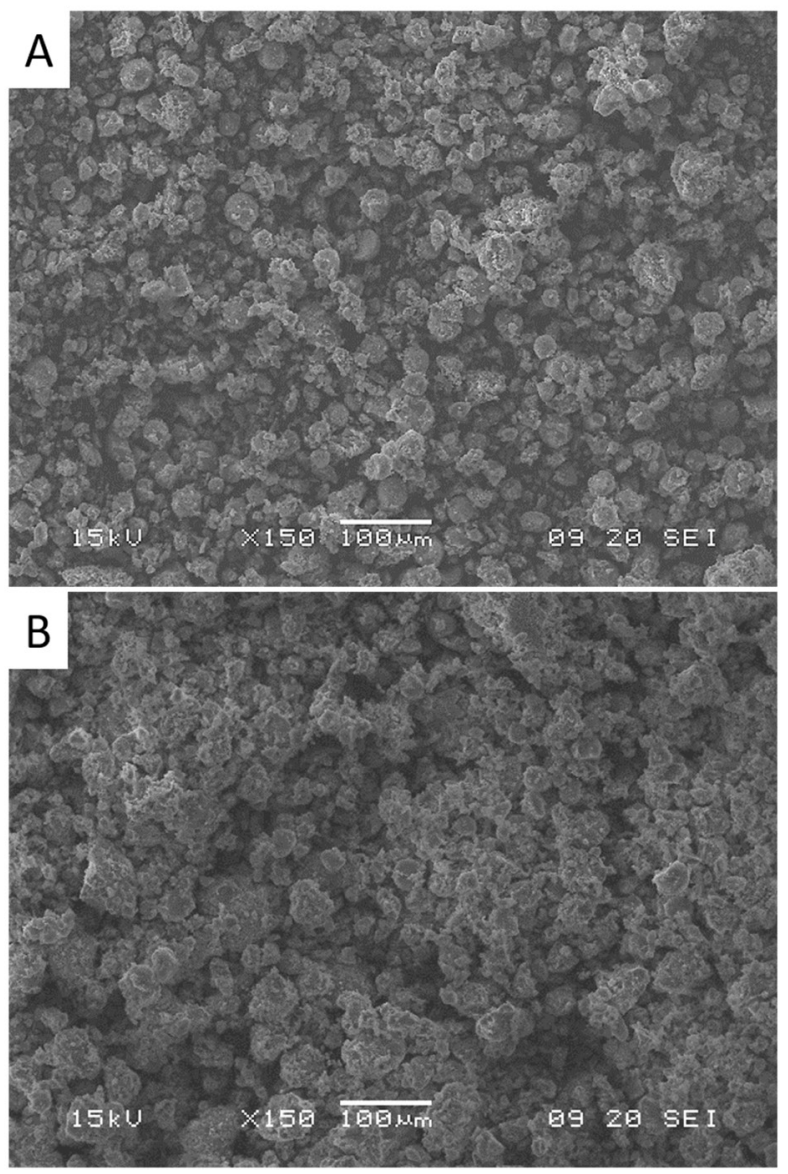

Fig. 5 Electron microscopic images of fresh A and used $L e-\mathrm{SG}-2$ biocatalyst after five reaction cycles B at different magnifications

Table 4 Comparison of the storage stability of the Lodderomyces elongisporus whole-cells in their different forms

\begin{tabular}{ccc}
\hline Whole-cell biocatalyst & after 6 month at $4{ }^{\circ} \mathrm{C}$ \\
freshly harvested cell paste & $\begin{array}{c}U_{\mathrm{B}}^{\mathrm{a}} \\
(\%)\end{array}$ & $\begin{array}{c}x_{2}^{\mathrm{b}} \\
(\%)\end{array}$ \\
\hline lyophilized cell powder & 0 & 0 \\
in $1^{\text {st }}$ generation sol - gel system & 42.2 & 4 \\
in $2^{\text {nd }}$ generation sol - gel system $(\mathrm{Le}-\mathrm{SG}-2)$ & 15.8 & $<1$ \\
\hline
\end{tabular}
${ }^{\mathrm{a}} U_{\mathrm{B}}$ biocatalytic activity, ${ }^{\mathrm{b}} x_{2}$ is the amount of $(R)-2$ in the mixture, calculated from $\mathrm{GC}$ data.

In contrast to the freshly harvested cell paste or the lyophilized cell powder forms, the novel immobilized form was able to conserve the biocatalytic activity the immobilized yeast cells and provided excellent reusability (biocatalyst recovery in five consecutive reaction cycles) and storability (6-month storage at $\left.4{ }^{\circ} \mathrm{C}\right)$.

In conclusion, combination of organosilane-based sol gel network with hollow silica microspheres as proper support material can provide new generation hybrid wholecell biocatalysts as promising sustainable alternative to the equipment- and cost-demanding lyophilization. 


\section{Acknowledgement}

Authors BWD and LP thanks the financial support for Excellence Program of the Ministry of Human Capacities in the frame of Biotechnology research area of Budapest University of Technology and Economics (BME FIKP-BIO). CP and LP thank the COST Action

\section{References}

[1] Wachtmeister, J., Dörte, R. "Recent Advances in whole cell biocatalysis techniques bridging from investigate to industrial scale", Current Opinion in Biotechnology, 42, pp. 169-177, 2016. https://doi.org/10.1016/j.copbio.2016.05.005

[2] Lin, B., Tao, Y. "Whole-cell biocatalysts by design", Microbial Cell Factories, 16(1), Article number: 106, 2017. https://doi.org/10.1186/s12934-017-0724-7

[3] Sheldon, R. A., Brady, D. "The limits to biocatalysis: pushing the envelope", Chemical Communications, 54(48), pp. 6088-6104, 2018. https://doi.org/10.1039/c8cc02463d

[4] Nagy-Győr, L., Abaházi, E., Bódai, V., Sátorhelyi, P., Erdélyi, B., Balogh-Weiser, D., Paizs, C., Hornyánszky, G., Poppe, L. "Co-immobilized Whole Cells with $\omega$-Transaminase and Ketoreductase Activities for Continuous-Flow Cascade Reactions", ChemBioChem, 19(17), pp. 1845-1848, 2018.

https://doi.org/10.1002/cbic.201800286

[5] Bickerstaff, G. F. "Immobilization of Enzymes and Cells", In: Bickerstaff, G. F. (ed.) Immobilization of Enzymes and Cells, Methods in Biotechnology, vol. 1, Humana Press, Totowa, NJ, USA, 1997, pp. 1-11.

https://doi.org/10.1385/0-89603-386-4:1

[6] Kometani, T., Yoshii, H., Matsuno, R. "Large-scale production of chiral alcohols with bakers' yeast", Journal of Molecular Catalysis B: Enzymatic, 1(2), pp. 45-52, 1996 https://doi.org/10.1016/1381-1177(95)00014-3

[7] Erdélyi, B., Szabó, A., Seres, G., Birincsik, L., Ivanics, J., Szatzker, G., Poppe, L. "Stereoselective production of $(S)$-1aralkyl- and 1-arylethanols by freshly harvested and lyophilized yeast cells", Tetrahedron: Asymmetry, 17(2), pp. 268-274, 2006. https://doi.org/10.1016/j.tetasy.2005.12.025

[8] Faber, K. "Biotransformations in Organic Chemistry", Springer, Berlin, Germany, 2011.

[9] Nikolova, P., Ward, P. O. "Whole cell yeast biotransformations in two-phase systems: Effect of solvent on product formation and cell structure", Journal of Industrial Microbiology, 10(3-4), pp. $169-177,1992$ https://doi.org/10.1007/BF01569762

[10] Bódai, V., Nagy-Györ, L., Örkényi, R., Molnár, Z., Kohári, S., Erdélyi, B., Nagymáté, Z., Romsics, C., Paizs, C., Poppe, L., Hornyánszky, G. "Wickerhamomyces subpelliculosus as wholecell biocatalyst for stereoselective bioreduction of ketones", Journal of Molecular Catalysis B: Enzymatic, 134, pp. 206-214, 2016. https://doi.org/10.1016/j.molcatb.2016.11.003

[11] Kostraby, M. M., Smallridge, A. J., Trewhella, M. A. "Yeast-mediated preparation of l-PAC in organic solvent", Biotechnology and Bioengineering, 77(7), pp. 827-831, 2002. https://doi.org/10.1002/bit.10117
SysBiocat (CM 1303) and project NEMSyB, ID P37_273, Cod MySMIS 103413 [funded by National Authority for Scientific Research and Innovation (ANCSI, Bucharest, Romania) and European Regional Development Fund, Competitiveness Operational Program 2014-2020 (POC), Priority axis 1, Action 1.1] for support.

[12] Mochizuki, N., Hiramatsu, S., Sugai, T., Ohata, H., Morita, H., Itokawa, H. "Improved Conditions for the Production and Characterization of 1-Arylpropane-1, 2-diols and Related Compounds", Bioscience, Biotechnology and Biochemistry, 59(12), pp. 2282-2291, 1995. https://doi.org/10.1271/bbb.59.2282

[13] Stump, B., Kieslich, K. "Acyloin condensation of acyclic unsaturated aldehydes by Mucor species", Applied Microbiology and Biotechnology, 34(5), pp. 598-603, 1991. https://doi.org/10.1007/BF00167906

[14] Bringer-Meyer, S., Sahm, H. "Acetoin and Phenylacetylcarbinol Formation by the Pyruvate Decarboxylase of Zymomonas mobilis and Saccharomyces carlsbergensis", Biocatalysis, 1(4), pp. 321-331, 1988. https://doi.org/10.3109/10242428808998172

[15] Ge, X., Yang, L., Xu, J. "Cell Immobilization: Fundamentals, Technologies, and Applications", In: Wittmann, C., Liao, J. C. (eds.) Industrial Biotechnology: Products and Processes, Wiley-VCH Verlag GmbH \& Co. KGaA, Weinheim, Germany, 2016, pp. 205-235. https://doi.org/10.1002/9783527807833.ch7

[16] Guisan, J. M. "Immobilization of Enzymes as the 21st Century Begins: An Already Solved Problem or Still an Existing Challenge?", In: Guisan, J. M. (ed.) Immobilization of Enzymes and Cells, Methods in Biotechnology, vol. 22, Humana Press, Totowa, NJ, USA, 2006, pp. 1-13. https://doi.org/10.1007/978-1-59745-053-9_1

[17] Weiser, D., Nagy, F., Bánóczi, G., Oláh, M., Farkas, A., Szilágyi, A., László, K., Gellért, Á., Marosi, G., Kemény, S., Poppe, L. "Immobilization engineering-How to design advanced sol-gel systems for biocatalysis?", Green Chemistry, 19(16), pp. 3927-3937, 2017. https://doi.org/10.1039/C7GC00896A

[18] Bartha-Vári, J. H., Bencze, L. C., Bell, E., Poppe, L., Katona, G., Irimie, F. D., Paizs, C., Tosa, M. I. "Aminated Single-walled Carbon Nanotubes as Carrier for Covalent Immobilization of Phenylalanine Ammonia-lyase", Periodica Polytechnica Chemical Engineering, 61(1), pp. 59-66, 2017. https://doi.org/10.3311/PPch.10417

[19] Mattaison, B. "Immobilized Cells and Organelles", vol. 1, CRC Press, Boca Raton, FL, USA, 2018. https://doi.org/10.1201/9781351073394

[20] Cassidy, M. B., Lee, H., Trevors, J. T. "Environmental applications of immobilized microbial cells: A review", Journal of Industrial Microbiology, 16(2), pp. 79-101, 1996. https://doi.org/10.1007/BF01570068 
[21] Buke, C. "[15] Cell immobilization in calcium alginate", Methods in Enzymology, 135, pp. 175-189, 1987. https://doi.org/10.1016/0076-6879(87)35076-1

[22] Zielinski, B. A., Aebischer, P. "Chitosan as a matrix for mammalian cell encapsulation", Biomaterials, 15(13), pp. 1049-1056, 1994. https://doi.org/10.1016/0142-9612(94)90090-6

[23] Hoffman, A. S. "Immobilization of Biomolecules and Cells on and within Polymeric Biomaterials", Clinical Materials, 11(1-4), pp. 61-65, 1992. https://doi.org/10.1016/0267-6605(92)90030-W

[24] De Vitis, V., Dall'Oglio, F., Pinto, A., De Micheli, C., Molinari, F., Conti, P., Romano, D., Tamborini, L. "Chemoenzymatic Synthesis in Flow Reactors: A Rapid and Convenient Preparation of Captopril", Chemistry Open, 6(5), pp. 668-673, 2017. https://doi.org/10.1002/open.201700082

[25] Eş, I., Gonçalves Vieira, J. D., Amaral, A. C. "Principles, techniques, and applications of biocatalyst immobilization for industrial application", Applied Microbiology and Biotechnology, 99(5), pp. 2065-2082, 2015 . https://doi.org/10.1007/s00253-015-6390-y

[26] Braun, S., Rappoport, S., Zusman, R., Avnir, D., Ottolenghi, M. "Biochemically active sol-gel glasses: the trapping of enzymes", Materials Letters, 10(1-2), pp. 1-5, 1990. https://doi.org/10.1016/0167-577X(90)90002-4

[27] Hench, L. L., West, J. K. "The sol-gel process", Chemical Reviews, 90(1), pp. 33-72, 1990. https://doi.org/10.1021/cr00099a003

[28] David, A. E., Yang, A. J., Wang, N. S. "Enzyme Stabilization and Immobilization by Sol-Gel Entrapment", In: Minteer, S. D. (ed.) Enzyme Stabilization and Immobilization: Methodes and Protocols, Methods in Molecular Biology, vol. 679, Humana Press, Totowa, NJ, USA, 2011, pp. 49-66. https://doi.org/10.1007/978-1-60761-895-9_6

[29] Dave, B. C., Dunn, B., Silverstone Valentine, J., Zink, J. I. "Sol-gel encapsulation methods for biosensors", Analytical Chemistry, 66(22), pp. 1120-1127, 1994. https://doi.org/10.1021/ac00094a001

[30] Klein, L. C. "Sol-Gel Optics: Processing and Applications", The Springer International Series in Engineering and Computer Science, vol. 259, Springer, Boston, MA, USA, 1994. https://doi.org/10.1007/978-1-4615-2750-3

[31] Kócs, L., Albert, E., Tegze, B., Kabai-Faix, M., Major, C., Szalai, A., Basa, P., Hórvölgyi, Z. "Silica Sol-gel Coatings with Improved Light Transmittance and Stability", Periodica Polytechnica Chemical Engineering, 62(1), pp. 21-31, 2018. https://doi.org/10.3311/PPch.10550

[32] Pressi, G., Dal Toso, R., Dal Monte, R. "Production of Enzymes by Plant Cells Immobilized by Sol-Gel Silica", Journal of Sol-Gel Science and Technology, 26(1-3), pp. 1189-1193, 2003. https://doi.org/10.1023/a:1020704118146

[33] Fennouh, S., Guyon, S., Livage, J., Roux, C. "Sol-Gel Entrapment of Escherichia coli", Journal of Sol-Gel Science and Technology, 19(1-3), pp. 647-649, 2000.

https://doi.org/10.1023/A:1008733916175
[34] Coiffier, A., Coradin, T., Roux, C., Bouvet, O. M. M., Livage, J. "Sol-gel encapsulation of bacteria: a comparison between alkoxide and aqueous routes", Journal of Materials Chemistry, 11(8), pp. 2039-2044, 2001.

https://doi.org/10.1039/B101308O

[35] Desimone, M. F., Degrossi, J., D'Aquino, M., Diaz, L. E. "Sol-gel immobilisation of Saccharomyces cerevisiae enchances viability on organic media", Biotechnology Letters, 25(9), pp. 671-674, 2003. https://doi.org/10.1023/A:1023481304479

[36] Inama, L., Diré, S., Carturan, G., Cavazza, A. "Entrapment of viable microorganisms by $\mathrm{SiO}_{2}$ sol-gel layers on glass surfaces: Trapping, catalytic performance and immobilization durability of Saccharomyces cerevisiae", Journal of Biotechnology, 30(2), pp. 197-210, 1993.

https://doi.org/10.1016/0168-1656(93)90113-2

[37] Lilao, J., Mateo, J. J., Maicas, S. "Biotechnological activities from yeasts isolated from olive oil mills", European Food Research and Technology, 240(2), pp. 357-365, 2015. https://doi.org/10.1007/s00217-014-2335-4

[38] Andreu, C., Ií del Olmo, M. "Biotransformation using halotolerant yeast in seawater: a sustainable strategy to produce $R-(-)$ phenylacetylcarbinol", Applied Microbiology and Biotechnology, 102(11), pp. 4717-4727, 2018. https://doi.org/10.1007/s00253-018-8945-1

[39] Ghosh, S., Banoth, L., Banerjee, U. C. "Biocatalytic deracemization: An efficient one-pot synthesis of $(R)$ - $\alpha$-methyl-4pyridinemethanol using whole cells of Candida parapsilosis", Biocatalysis, 1(1), pp. 59-66, 2015.

https://doi.org/10.1515/boca-2015-0004

[40] Shimada, K., Kimura, E., Yasui, Y., Tanaka, H., Matsushita, S., Hagihara, H., Nagakura, M., Kawahisa, M. "Styrene Formation by the Decomposition by Pichia carsonii of trans-Cinnamic Acid Added to a Ground Fish Product", Applied and Environmental Microbiology, 58(5), pp. 1577-1582, 1992.

[41] Oláh, M., Suba, S., Boros, Z., Kovács, P., Gosselin, M., Gaudreault, C., Hornyánszky, G. "Lipase B from Candida antarctica Immobilized on Epoxy-functionalized Hollow Silica Microspheres: Efficient Biocatalysts for Enantiomer Selective Acylation of Alcohols and Amines", Periodica Polytechnica Chemical Engineering, 62(4), pp. 519-532, 2018. https://doi.org/10.3311/PPch.12517

[42] Nagy, F., Szabó, K., Bugovics, P., Hornyánszky, G. "Bisepoxideactivated Hollow Silica Microspheres for Covalent Immobilization of Lipase from Burkholderia cepacia", Periodica Polytechnica Chemical Engineering, 63(3), pp. 414-424, 2019. https://doi.org/10.3311/PPch.12665

[43] Dyda, F., Furey, W., Swaminathan, S., Sax, M., Farrenkopf, B., Jordan, F. "Catalytic Centers in the Thiamin Diphosphate Dependent Enzyme Pyruvate Decarboxylase at 2.4-£ Resolution", Biochemistry, 32(24), pp. 6165-6170, 1993. https://doi.org/10.1021/bi00075a008

[44] Lobell, M., Corut, D. H. G. "Pyruvate Decarboxylase: A Molecular Modeling Study of Pyruvate Decarboxylation and Acyloin Formation", Journal of American Chemical Society, 118(8), pp. 1867-1873, 1996. https://doi.org/10.1021/ja951830t 